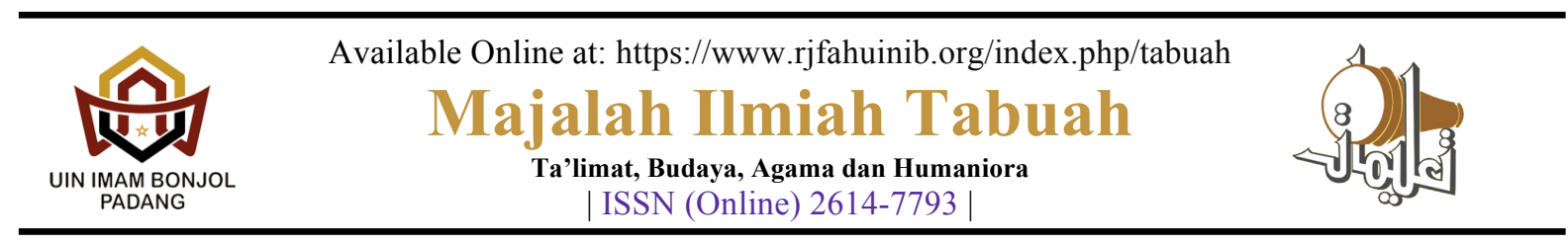

\title{
PERAN STRATEGIS PITI SUMATERA BARAT
}

\author{
Doni Nofra \\ Sejarah Peradaban Islam Fakultas FUAD, IAIN Bukittinggi \\ email:doninofra25@gmail.com \\ Inggria Kharisma \\ email: inggriakharisma@gmail.com
}

\begin{abstract}
The Government of Indonesia released different terms related to the Chinese: Cina, China, Tionghoa and Tiongkok. Cina is a term for people with Chinese passport living in Japan, Malaysia, Singapore, Taiwan, and even in Indonesia, i.e. foreign nationals. The term China (with an 'h') is an official writing issued by the Embassy of the People's

Republic of China to refer to the citizens of the People's Republic of China (PRC) in Bahasa Indonesia. The term Tionghoa is used to designate those of Chinese descent living in Indonesia. Meanwhile, Tiongkok is how Bahasa Indonesia refers to the citizens of the People's Republic of China. On March 14, 2014 President SBY changed the term

China to Tiongkok by issuing the Presidential Decree No. 12. The history of Chinese Muslims in West Sumatera cannot be separated from the history of the arrival of Islam into the Archipelago. The term Tionghoa refers to the people of Chinese origins.

According to Ernawati, in her Asap Hio di Ranah Minang, the Chinese people have been living in Pariaman since the 12th century CE. When Aceh occupied Pariaman, the region became a safe haven for merchants.
\end{abstract}

Keywords: Strategic Role, PITI, West Sumatra

\begin{abstract}
Abstrak
Indonesia merilis perbedaan istilah-istilah tersebut, yaitu Cina, China, Tionghoa dan Tiongkok. Cina adalah sebutan untuk orang yang berwarga negara Cina yang setara dengan orang Jepang, Malaysia, Singapura, Taiwan, dan Indonesia yang berarti warga negara asing. Kemudian China (dengan tambahan ' $h$ ') adalah penulisan resmi oleh Kedutaan Republik Rakyat Cina yang merujuk pada negara Republik Rakyat China $(R R C)$ dalam bahasa Indonesia. Istilah Tionghoa adalah sebutan untuk orang-orang keturunan Cina di Indonesia yang sepadan dengan orang Jawa, Sunda, Madura, Batak, dan lain-lain.Sedangkan Tiongkok adalah penyebutan negara China untuk Indo-nesia. Dalam kaitan ini Presiden SBY pada 14 Maret 2014mengubah istilah China dengan sebutan Tionghoa. Pencabutan surat edaran itu berdasarkan Keppres Nomor 12 Tahun 2014 yang ditandatanganinya. Sejarah tentang Muslim Tonghoa di Sumatera Barat
\end{abstract}


tidak dapat dipisahkan dari sejarah masuknya agama Islam ke wilayah Nusantara,Muslim Tionghoa merupakan salah satu komunitas masyarakat yang berada di Indonesia yang berasal dari Tionghoa. Sebutan Tionghoa merujuk kepada identitas masyarakat yang berasal dari kawasan Tiongkok. Teori lain tentang keberadaan China di Padang adalah berasal dari Pariaman. Menurut Ernawati, dalam buku Asap Hio di

Ranah Minang, bahwa komunitas Tionghoa di Sumatera Barat sudah berada di Pariaman sejak abad XII Masehi. Saat Aceh masuk ke Pariaman, kawasan ini menjadi surga bagi kaum pedagang di zaman itu.

Kata kunci: Peran Strategis, PITI, Sumatera Barat.

\section{PENDAHULUAN}

Istilah Cina, China, Tionghoa dan Tiongkok

Sebelum mengurai masuknya Tionghoa Muslim ke Suma-tera Barat, perlu dijelaskan mengenai perbedaan sebutan China-Cina dan TionghoaTiongkok. Pembedaan ini penting karena kedu-anya memiliki kaitan dengan identitas keagamaan yang dianut. Paguyuban Sosial Marga Tionghoa Indonesia merilis perbedaan istilah-istilah tersebut, yaitu Cina, China, Tionghoa dan Tiongkok. Cina adalah sebutan untuk orang yang berwarga negara Cina yang setara dengan orang Jepang, Malaysia, Singapura, Taiwan, dan Indonesia yang berarti warga negara asing. Kemudian China (dengan tambahan ' $h$ ') adalah penulisan resmi oleh Kedutaan Republik Rakyat Cina yang merujuk pada negara Republik Rakyat China (RRC) dalam bahasa Indonesia. Istilah Tionghoa adalah sebutan untuk orangorang keturunan Cina di Indonesia yang sepadan dengan orang Jawa, Sunda, Madura, Batak, dan lain-lain.Sedangkan Tiongkok adalah penyebutan negara China untuk Indo-nesia. Dalam kaitan ini Presiden SBY pada 14 Maret 2014mengubah istilah China dengan sebutan Tionghoa. Pencabutan surat edaran itu berdasarkan Keppres Nomor 12 Tahun 2014 yang ditekennya. ${ }^{1}$

Lalu dari mana munculnya istilah "China dan Tiongkok"? Untuk ini dapat dirujuk kembali penggunaan terjemahan dari "Zhong Hua Ren Min Gong He Guo", yang dalam bahasa Inggris diartikan sebagai "People's Republic of China". Di kalangan institusi Pemerintah Indonesia, masih belum dibakukan apa terjemahan dari "Zhong Hua Ren Min Gong He Guo", apakah "Republik Rakyat Tiongkok" (RRT) atau "Republik Rakyat Cina" (RRC) atau "Republik Rakyat China"? Tetapi dengan adanya Keppres yang dikeluarkan pada tahun 2014 yang lalu dapat dipastikan terjemahan "He Go" adalah Tiongkok, bukan China.Di berbagai media. baik di televisi maupun surat kabar sudah menggunakan kata "Tiong-kok". Secara linguistik, istilah "Tiongkok" dan "Tionghoa" hanya ditemukan di Indonesia karena lahir dari pelafalan "Zhong Guo" (Negara Tengah) dalam Bahasa Indonesia dan dialek Hokien (yang digunakan di

\footnotetext{
${ }^{1}$ Dalam keppres yang ditandatangani 14 Mare 2014, Presiden Susilo Bambang Yodoyono menilai bahwa perlakuan diskriminatif terhadap seseorang, kelompok, komunitas dan/atau ras tertentu pada dasarnya melanggar nilai atau prinsip perlindungan hak asasi manusia. Ini bertentangan dengan Undangundang Dasar Negara tentang Hak Asasi Manusia, dan Undang-undang tentang Penghapus-an Diskriminasi Ras dan Etnis.
} 
Provinsi Fujian, dimana banyak etnis Tionghoa di Indonesia berasal).

Kedua istilah tersebut tidak dikenal di negara-negara tetangga yang bahasanya juga mempunyai akar bahasa Melayu seperti Malaysia dan Brunei Darussalam. Pada permulaan Abad ke19, masyarakat Tionghoa di Indonesia mengurangi penyebutan istilah "Cina" (pada saat itu ditulis "Tjina") dalam berbagai pub-likasi dan percakapan publik karena dianggap merendahkan. Sebagai gantinya, istilah "Tiongkok" digunakan untuk penyebutan negara, dan "Tionghoa" untuk sebutan orang.Tetapi pada tahun 1967, pemerintah saat itu melarang penggunaan kata "Tionghoa" dan "Tiongkok" karena nilai-nilai psikologis yang dianggap meru-gikan Indonesia. Maka dikeluarkan keputusan yang disahkan oleh Presidium Kabinet Ampera pada 25 Juli 1967 dengan pertimbangan bahwa istilah tersebut adalah yang "disenangi rakyat Indonesia".

Kemudian diterbitkan Surat Edaran Presidium Kabinet Ampera Nomor 6 Tentang Masalah Cina. Pada tanggal 6 Desember 1967, ditetapkan Inpres Nomor 14 Tentang Agama Kepercayaan dan Adat Istiadat Cina, yang tujuannya untuk semakin menekan kebebasan berekspresi masyarakat Tionghoa di Indonesia. Sejak itu, praktis tidak pernah lagi terdengar penggunaan istilah "Tiong-kok" dan "Tionghoa" dalam kehidupan seharihari rakyat Indo-nesia. Yang ada hanya istilah "Cina", yang walaupun secara tata bahasa dinilai netral, namun kerap digunakan dengan tendensi merendahkan. Tetapi ketentuan tersebut sudah dicabut oleh pemerintah.Belum lagi kejadian yang terjadi pada tahun 1998 yang menjadikan etnis Tionghoa semakin tertekan.

Perkembangan berikutnya, muncul istilah "pribumi" dan "NonPribumi"yang menjadi masalah serius pasca kerusuhan 1998. Tetapi beruntung setelah zaman reformasi, Presiden
Abdurrahman Wahid melakukan pencabutan atas Inpres No. 14 Tahun 1967 yang dianggap diskriminatif dan tidak sesuai dengan norma-norma reformasi. Presiden Abdurrahman Wahid adalah salah satu tokoh reformasi yang memelopori penggunaan kembali istilah "Tiongkok" dan "Tionghoa".Di dalam laporan kerja Peme-rintah bulan Agustus 2000, Presiden Abdurrahman Wahid sudah secara tegas menggunakan sebutan "Republik Rakyat Tiongkok."

Dengan demikian istilah Tiongkok dan Tionghoa menjadi istilah yang baku menggantikan istilah sebelumnya, yaitu China atau Cina. Penggunaan istilah baru ini merujuk kepada upaya penekanan psikologis etnis Tionghoa sebagai bagian dari Negara Kesatuan Republik Indonesia.

\section{PEMBAHASAN}

\section{Sejarah Muslim Tionghoa di Indonesia}

Sejarah tentang Muslim Tonghoa tidak dapat dipisahkan dari sejarah masuknya agama Islam ke wilayah Nusantara. Para pakar sejarah memandang masuknya Islam di Indonesia merupakan proses yangsangat penting, tetapi dipandang sebagai sesuatu yang tidak begitu jelas dan debatable. ${ }^{2} \mathrm{Hal}$ ini lantaran banyak pandangan yang menyebut teori masuknya Islam ke Indoensia dikaitkan dengan India,Mekkah (Arab), Persia, Banglades, dan juga munculnya teori China.

Bentuk debatable teori masuknya Islam di Indonesia ini dapat dilihat dari adanya rangkaian jalur Islam pada masa awal sebagai berasal dari Bangla (sebutan untuk Banglades). Ada juga penanda batu nisan yang menjadi simbol makam orang Islam berasal dari Gujarat(sebutan untuk bangsa India saat

\footnotetext{
${ }^{2}$ Ricklefs, Sejarah Indonesia Modern 1200-2008, Jakarta: PT. Serambi Ilmu Sejahtera, 2010, h. 3
} 
itu). ${ }^{3}$ Kemudian adanya gelar yang disandang oleh masyarakat seperti gelar Syaikh, Said, Syarif menunjukkan identitas tentang bangsa Arab. ${ }^{4}$ Tentu saja pandangan-pandangan tersebut mengarahkan kepada kesimpulan yang beragam tentang masuknya Islam ke wilayah Indonesia.

Azyumardi Azra, pakar sejarah Islam Indonesia, merilis beberapa teori tentang masuknya Islam ke Indonesia. Menurut Azra kemunculan Islam di Nusantara dimulai sejak kebangkitan Islam sampai paruh kedua abad-17 dengan menempuh beberapa fase. Fase pertama, sejak akhir abad ke- $8 \mathrm{M}$ sampai ke-12 Mditandai dengan hubungan perdagangan.Inisiatif dalam hubungan sema-cam ini secara umum dilakukan oleh kalangan masyarakat Muslim dari TimurTengah, khususnya Arab dan India. Fase kedua, dari abad ke-12 M sampai akhir abad ke -15, hubungan antara bangsa Arab dan India mengambil aspek aspek lebihluas. Muslim Arab dan India yang terdiri dari pedagang atau pengembara sufi,mulai mengintensifikasikan penyebaran Islam di berbagai wilayah Nusantara.Pada tahap ini hubungan keagamaan dan kultural terjalin lebih erat. Kemudian pada tahap berikutnya, yaitu sejak abad ke-16 sampai paruh kedua abad ke-17 yang ditandai dengan hubungan yang mengarah ke ranah politis di samping keagamaan itu sendiri. ${ }^{5}$

Pertama, Teori Gujarat. Teori Gujarat ${ }^{6}$ didasarkan atas pandangan

${ }^{3}$ M. Abdul Karim. "Teori Jalur India Tentang Masuknya Islam di Indonesia (Studi Teori Bangla dan Gujarat)", Makalah tanpa tahun terbit, h. 15

${ }^{4}$ M. Naquib al-Attas, Islam and Secularisme, Kuala Lumpur: ISTAC, 1993, h. 15

${ }^{5}$ Azyumardi Azra, Jaringan Ulama Timur Tengah dan Kepulauan Nusantara Abad XVII \& XVII: Akar Pembaharuan Islam Indonesia, Jakarta: kencana Prenada MediaGroup, 2004, h. 50

${ }^{6}$ Gujarat, yaitu negara bagian India paling terindustrialisasi di India setelah Maharashtra dan terletak di barat India, berbatasan dengan Pakistan di barat laut dan yang mengatakan asal daerahyang membawa Islam ke Nusantara adalah dari Gujarat. Menurut AbdulGhofur, peletak dasar teori ini pertama dikemukakan oleh Pijnepel (1872 M)yang menafsirkan catatan perjalanan Sulaiman, ${ }^{7}$ Marcopolo dan Ibn Batutah. ${ }^{8}$ Teori ini dikemudian hari mendapat dukungan dari Snouck Hurgronye yangmendasarkan kepada alasan-alasan beri-kut ini: pertama, kurangnya fakta yangmenjelaskan peranan bangsa Arab dalam penyebaran agama Islam keNusantara, kedua, hubungan dagang. antara IndonesiaIndia telah lama terjalindengan baik; ketiga, Inskripsi tertua tentang Islam

Rajasthan di utara. Ibu kotanya adalah Gandhinagar, sebuah kota terencana dekat Ahmedabad, bekas ibu kota negara bagian dan pusat komersial Gujarat. Negara bagian Gujarat diciptakan pada 1 Mei1960.

${ }^{7}$ Namanya Sulaiman Al-Mahiri hidup pada abad ke-16 M. Ia anggota suku yang hidup didaerah selatan jazirah arabia, suku mahara. Masa muda Sulaiman tak banyak diketahui, ia melakukan eksplorasi dunia yang luas di hampir semua samudra besar di dunia dan telah merangkumkan pengalamannya dalam beberapa uraian yang ditulisnya dalam 50 bagian, tahun pertama abad ke-16. Pelayaran pertama yang dicatat sulaiman dimulai dari samudra india dan setelah melewati samudra fasifik, selat Bering, samudra afrika, atlantik masuk ke laut tengah melewati selat Gibraltar. Rute yang lainnya mulai dari samudra india, menyebrangi laut Abysinia terusan Mozambik dan mengitari tanjung harapan serta samudra Atlantik, terus masuk laut tengah lewat selat Gibraltar. Rute ini adalah rute Vasco De Gama. Sulaiman AlMahiri menulis uraian-uraian penting berisi keterangan brharga mengenai ilmu nautika, bintang-bintang, planet-planet, jalur pelayaran, angin, dan daerah-daerah pantai.Sulaiman AlMahiri bukan hanya seorang penjelajah besar, yang telah menjelajahi laut-laut yang jauh dan belum pernah dijelajahi. Ia juga seorang penulis yang memberikan sumbangan sangat berarti bagi pengetahuan tentang ilmu astronomi, nautika (bahari), dan geografi abad pertengahan.

${ }^{8}$ Abd. Ghofur, "Tela'ah Kritis Masuk dan Berkembangnya Islam di Nusantara" dalam Jurnal Ushuluddin, Vol. XVII No. 2, Juli 2011, h. 161 
yang terdapat di Sumateramemberikan gambaran hubungan dagang antara Suma-tera dan Gujarat. ${ }^{9}$

Azyumardi menambahkan Islam menyebar dan cukup kuat pada masaitu dan menduduki kota-kota di pelabuhan, salah satunya kota Deccan,dimana mayoritas penduduknya beragama Islam dan berprofesi sebagai pedagang. Orang Deccan inilah yang berperan menyebarkan Islam di Indonesia melaluijalur perda-gangan. ${ }^{10}$ Pandangan Snouck Hurgronye tersebut memiliki pengaruh besar padamasa-masa selanjutnya karena mendapat legi-timasi dari sejarawan Barat antaralain Stutterheim dalam karyanya (De Islam en Zijn Komst in De Archple),Bernard H.N. Vlekke, (Nusantara A History of Indonesia), BJO. Schriekie(Indonesian Sociological Studies), Clifford Geertz (The Religion of Java), Harry J. Benda (A History of Modern South East Asia) Van Leur (IndonesianTrade And Society), T.W. Arnold (The Preaching of Islam). ${ }^{11}$ Moquette, seorang sarjana Belanda lainnya berkesim-pulan bahwatempat asal Islam di Nusantara adalah Gujarat. Kesimpulannya muncul setelahia mengamati bentuk batu nisan di Pasai, kawasan Utara Sumatra (Acehsekarang) khususnya yang bertanggal 17 Dzulhijjah 831H/ 27 September1428M. Batu Nisan yang kelihatannya mirip dengan batu nisan lain yangditemukan di makam Maulana Malik Ibrahim (w.822/1419M) di Gresik JawaTimur ternyata sama bentuknya dengan batu nisan yang terdapat di CambayGujarat. Berdasarkan contoh-contoh batu nisan inilah ia berkesimpulan bahwabatu nisan dari Gujarat bukan hanya untuk pasar local, tetapi juga diimpor kekawasan lain. Salah satunya ke wilayah Nusantara. $^{12}$

\footnotetext{
${ }^{9}$ Abd. Ghofur, "Tela'ah Kritis..., h. 162

${ }^{10}$ Azra, Jaringan Ulama, h. 40

${ }^{11}$ Lihat, Ahmad Mansur Surya Negara, Menemukan Sejarah, Wacana Pergerakan Islam diIndonesia, Bandung: Mizan 2002, h. 75-78.

${ }^{12}$ Azra, Jaringan Ulama, h. 25
}

Dari penjelasan di atas dapat disimpulkan bahwa Islam masuk keIndonesia melalui pedagang India yang beragama Islam. Masuknya Islam diIndonesia (menurut teori India) sekitar abad ke 12M. Bukti corak Indianyaberasal dari batu nisan yang ditemukan pada makam orang Islam di Indonesia.Batu Nisan inilah yang menjadi bukti identitas antara Islam, India danIndonesia saling berhubungan.

Kedua, Teori Arab.Teori masuknya Islam melalui Arab lahir atas kritik terhadap teorimasuknya Islam dari India. Salah satu bentuk kritiknya adalah fakta mayoritasmuslim Indonesia bermadzhab Syafi'i menunjukkan bukan berasal dari India,melainkan dari Arab. Fajar Affandi dalam sebuah penelitiannya mengutip dariAlwi bahwa Snouck mengakui bahwa madzhab Syafi'i yang ada di Indonesiamemungkinkan berasal dari Arab yang bermigrasi ke India. Dengan kata lainIndia hanya sebatas tempat transit semata. ${ }^{13}$

Salah satu sejarawan Barat yang pernah memunculkan teori Arab adalah Crawfurd (1820 M), Keyzer (1859 M), Veith (1878 M). Umumnya sejarawan nusantara yang giat memperjuangkan dan mendukung teori Mekkah adalah mereka yang terlibat langsung dan tak langsung dalam seminar tentang masuk dan berkembang-nya Islam di Nusantara, baik di Medan maupun di Aceh.

Di antara sejarawan paling gigih memperjuangkan teori ini adalah HAMKA dan M. Naquib al-Attas. Hamka menilai wilayah Gujarat bukan tempat asal datangnya Islam,tetapi Gujarat hanya sebagai tempat singgah dari saudagar-saudagar Arabseperti dari Mekkah, Mesir dan Yaman. Sebenarnya Mekkah atau Mesir adalahtempat asal pengambilan ajaran Islam. Ia juga

\footnotetext{
${ }^{13}$ Fajar Apandi, "Islamisasi di Jawa Barat Abad XV”, Skripsi Fakultas Adab danHumaniora, UIN Syarif Hidayatullah Jakarta, 2011, h. 34 .
} 
mendasarkan bahwa mazhabterbesar yang dianut sebagian besar umat Islam Nusantara adalah MazhabSyafii sama dengan mazhab yang sama dianut masyarakat Mekkah masa itu,alasan ini jarang diungkap sejarawan Barat masa awal.Lain halnya Naquib al-Attas yang berpendapat bahwa tidak ada satupun karyaliteratur yang relevan berasal dari India. Memahami karakteristik internalIslam sangatlah penting, sehingga mengenai bahwa Islam datang tidak hanyaberasal dari unsur eksternalnya saja. Kebanyakan literatur justru berasal dariJazirah Arab, atau setidaknya dari Persia. ${ }^{14}$ Selain itu penggunaan gelar Syarif,Said, Muhammad, Maulana juga identik dengan asal mereka dari Mekkah dankedatangan mereka termasuk paling awal di kawaasan Nusantara ini. Buktilain adalah pada tahun $1297 \mathrm{M}$ Gujarat masih berada di bawah naungankerajaan Hindu, setahun kemudian baru ditaklukkan tentara muslim. $^{15}$

Dengan demikian, teori Arab mendasarkan pandangan masuknya Islamdiidentikan dengan unsur internal Islam itu sendiri. Arab merupakan permulaanIslam muncul, oleh karena itu bangsa Arab-lah yang menyebarluaskan Islam, termasuksampai ke wilayah Nusantara. Unsur internal lain adalah literatur sebagaisumber-sumber Islam juga menunjukkan bukti bahwa Islam berasal dari Arab. Namun yang masih menjadi catatan adalah Arab yang dimaksud secara umum merupakan jazirah arab, tidak diidentikan secara pasti apakah Saudi Arabia, Mesir atau Iraq dan sebagainya. Semuanya terangkum dalam satu kawasan jazirahArabia.

Ketiga, Teori Persia. Teori masuknya Islam ke Indonesia melalui orang-orang Persia seperti dikemukakan oleh P.A. Hoesin Djajadiningrat dari Indonesia.Titik pandang teori ini

14 Naquib al-Attas, Islam dalam Sejarah Melayu, Bandung: Mizan, 1997, h. 55.

${ }^{15}$ Abd. Ghofur, "Telaah Kritis", h. 163 memiliki perbedaan dengan teori Gujarat dan Mekkahmengenai masuk dan datangnya Islam di Nusantara. Islam masuk ke Indonesiamenurut Hossen Djajadiningrat berasal dari Persia abad ke-7 M. Dasar dariteori Persia ini adanya perkumpulan orangorang Persia di Aceh sejak abad ke-15. Pada saat itu pemakaian gelar Syah yang biasa digunakan di Persia, jugapernah digunakan raja-raja. ${ }^{16}$

Teori ini memfokuskan tinjauannya pada sosio-kultural di kalanganmasyarakat Islam Indonesia yang ada kesamaan dengan di Persia. Diantaranyaadalah perayaan Tabut di beberapa tempat di Indonesia, dan berkembangnyaajaran Syeikh Siti Jenar zaman penyebarann Islam Wali Sanga ada kesamaandengan ajaran Sufi alHallaj dari Iran Persia. ${ }^{17}$ Selain itu, terdapat persamaanbudaya antara masyarakat Indonesia dengan Persia. Contohnya, peringatan hariAsyura pada tanggal 10 Muharram atas wafatnya cucu Nabi Muhammad Saw,yaitu Hasan dan Husain. ${ }^{18}$

Teori ini banyak mendapat kritikan ketika diadakan seminar tentang masuk dan berkembangnya Islam di Indonesia diseleng-garakan di Medan tahun 1963 M. Kritik itu muncul dari Dahlan Mansur, Abu Bakar Atceh, Saifuddin Zuhri, dan HAMKA. Penolakan teori ini didasarkan pada alasan bahwa, bila Islam masuk abad ke-7 M. yang ketika itu kekuasaan dipimpin Khalifah Umayyah (Arab), sedangkan Persia Iran belum menduduki kepe-mimpinan dunia Islam. Danmasuknya Islam dalam suatu wilayah, bukankah tidak identik langsungberdirinya kekuasaan politik Islam. ${ }^{19}$

${ }^{16}$ Rosita Baiti, "Teori Dan Proses Islamisasi Di Indonesia” dalam Jurnal Wardah, no.XXVIII/ th. XV/Desember 2014, h. 140.

${ }^{17}$ Abd. Ghofur, "Telaah Kritis", h. 162.

${ }^{18}$ Rosita Baiti, "Teori Dan Proses Islamisasi" h. 141

${ }^{19}$ Abd. Ghofur, "Telaah Kritis", h. 164 
Dari penjelasan di atas, secara umum tiga teori masuknya Islam salingmengisi dan mengritik satu sama lain. Teori masuknya Islam dari berbagaidaerah merupakan kerangka dasar bagaimana memahami proses penyebaranIslam atau Islamisasi yang terjadi di Indonesia. Dalam konteks IslamIndonesia, isu penting yang berkembang sejak awal proses Islamisasi adalahperjalanan masuk-nya Islam itu sendiri serta media yang digunakan masuknyaIslam di Indonesia. Di luar tiga teori tadi dapat juga dijadikan bahan renungan tentang corak ajaran Islam yang menjadi isu sentral dalam masuknyaIslam di Indonesia. Di setiap wilayah, Islam berkem-bang dengan pesat, baik pada level kerajaanmaupun masyarakat. Pada level-level tersebut hampir dapat dilihat secara sekeluruhan bahwa sufisme senantiasa mewarnai secara gambaran Islam yang munculdi Indonesia. ${ }^{20} \mathrm{Hal}$ tersebut disebarluaskanmelalui kegiatan kaum pedagang dan sufi yang disebut kemudian dengan neo-sufisme. ${ }^{21}$

Maka, dari tiga teori tentang masuk dan berkembangnya Islam di Indonesia, serta teori tentang corak sufisme di kalangan umat Islam saat itu memberikan gambaran bahwa pintu masuk agama Islam ke tanah air sangat terbuka, tanpa melalui peperangan, pertumpahan darah ataupun cara-cara konfrontatif. Dalam hal ini jejak orangorang Gujarat (India), Mekkah (Arab) ataupun Persia -yang kesemuanya merupakan para pedagang membuktikan bahwa masuk dan berkembangnya Islam ke tanah air melalui mekanisme hubungan sosial yang terbuka dan inklusif. Terlebih corak yang ditampilkan juga banyak yang mengarah kepada corak sufistik.

\footnotetext{
${ }^{20}$ Rizal Sukma dan Clara Joewono, Gerakan Pemikiran Islam Indonesia Kontemporer, Yogyakarta: Kanisius, 2007, h. 250

${ }^{21}$ Ira Lapidus. M, Sejarah Sosial Umat Islam, Jakarta: PT Raja grafindo,1999, h.717
}

Cheng Ho: Legenda Tionghoa Muslim Indonesia

Muslim Tionghoa merupakan salah satu komunitas masyarakat yang berada di Indonesia yang berasal dari Tionghoa. Sebutan Tionghoa merujuk kepada identitas masyarakat yang berasal dari kawasan Tiongkok. Sebagian dari bangsa ini dalam sejarahnya masuk ke Indonesia melalui sebuah ekspedisi pelayaran melalui laut China selatan. Melalui ekspedisi tersebut bangsa Tionghoa ma-suk dan sebagiannya menetap di Indonesia. Para ahli sejarah me-nyebut di antara mereka terdapat bangsa Tionghoa yang beragama Islam, yang kemudian menjadi embrio eksistensi masyarakat Muslim Tionghoa di Indonesia.

Teori masuknya Islam ke Indonesia dari China didasarkan pada beberapahal. Pertama adanya catatan perjalanan Laksamana Cheng Ho. Kedua beberapapeninggalan purba atau benda fisik yang khas dengan China. Ketiga catatanpendukung penyebaran Islam oleh China di Indonesia. Teori masuknya Islam dari China dikemukakan oleh Slamet Muljana dalam bukunya Runtuhnya Kerajaan Hindu-Jawa dan Timbulnya Kerajaan Islamdi Nusan-tara, diterbitkan oleh LKiS, Yogryakarta. Secara umum teori ini belum dieksplorasi secara sungguhsungguh, padahalorang-orang Muslim China mempunyai peranan penting dalam prosespenyebaran agama Islam di Indonesia. ${ }^{22}$ Temuan Slamet Muljana diperkuat oleh temuan Sumanto AlQurtubi yang melansir eksis-tensiChina muslim pada awal perkembangan Islam di Jawa yang dapat dibuktikan denganpeningggalan purbakala Islam di Jawa. $^{23}$

\footnotetext{
${ }^{22}$ Slamet Muljana, Runtuhnya Kerajaan Hindu-Jawa dan Timbulnya Kerajaan Islamdi Nusantara, Yogyakarta: LKiS, 2007, h. v.

${ }^{23}$ Lihat, Sumanto al-Qurtuby, Arus China-Islam Jawa; Bongkar Sejarah Atas Peranan Tionghoa Dalam PenyebaranAgama Islam di Nusantara Abad XV-XVI
} 
Menurut Slamet Muljana, salah satu argumen teori masuk-nya Islam ke Indonesia melalui Chinaadalah adanya penjelajah asal China beragama Islam yang bernama Cheng Ho atau Zheng He atau Sam Po Kong. ${ }^{24}$ Catatan perjalanan Cheng Ho diawalidengan keberadaan Dinasti Ming (Zhu Di). Kebijakan yang diberikan olehDinasti Ming adalah memberikan hak bebas memeluk agama apa saja. Selainitu, Dinasti Ming juga memberikan kesempatan yang sama untuk semuajabatan sesuai dengan kemampuannya. ${ }^{25}$ Kon-disi di atas mendukung misi yang dimiliki Dinasti Ming berupamemperkenalkan kebesaran China ke seluruh dunia. Untuk mewu-judkan misi inilah Dinasti Ming mengutus Cheng Ho untuk melakukan ekspedisi memperkenalkankebesaran China ke ber-bagai kawasan di dunia. ${ }^{26}$

Cheng Ho yang merupakan seorang laksamana laut asal Tiongkok padaabad ke-15. Laksamana Cheng Ho lahir sekitar tahun $1371 \mathrm{M}$ di provinsi Yunan sebelah barat daya China. Cheng Ho -yang mempunyai nama kecil Ma Ho, tumbuh dan dibesarkan di lingkungan keluarga Muslim. Nama "Ma" sendiri merujuk pada nama "Muhammad"yang digunakan keluarga Muslim di Tiong-kok. ${ }^{27}$ Dalam pelayarannya Cheng Ho sempat singgah di Nusan-tara, selain untukmencapai tujuan yang diperintahkan oleh Dinasti

\footnotetext{
24 Slamet Muljana, Runtuhnya Kerajaan Hindu-Jawa dan Timbulnya KerajaanIslam di Nusantara, Yogyakarta: LKiS, 2007, h. v.

${ }^{25}$ Kong Yuanzhi, Muslim Tionghoa Cheng Ho: Misteri Perjalanan Muhibbah diNusantara, Jakarta: Yayasan Pustaka Obor, 2000, h. 32.

${ }^{26}$ Tan Ta Sen, Cheng Ho: Penyebar Islam Dari China ke Nusantara, Jakarta:Kompas, 2010, h. 223.

${ }^{27}$ Fadil Wicaksono, "Peranan Cheng Ho dalam Perkem-bangan Agama Islam diIndonesia Tahun 1405-1433” dalam Skripsi Universitas Pendidikan Indonesia, Bandung, 2014,h. 3
}

Ming untuk bersilaturahmidan memelihara perdamaian dengan warga setempat yang dikunjungi. Adapuntujuan dari Cheng Ho sendiri ingin memperkenalkan agama Islam bahwa Islamadalah agama yang cinta damai. Selain itu Cheng Ho turut sertamenye-barkannya namun tidak memaksakan kehendak karena Cheng Ho sendiriorang yang memiliki rasa toleransi tinggi. Hal tersebut dikarenakan di Chinasendiri Cheng Ho sangat menghargai agama Budha, Kong $\mathrm{Hu} \mathrm{Chu}$ dan agamalainnya. ${ }^{28}$

Sebagai seorang Muslim yang taat, Cheng Ho beberapa kali mengadakan kegiatan agama Islam, seperti melakukan dakwah di beberapa daerah yang di singgahi selama pelayaran, tak terkecuali di Indonesia. Cheng Hosinggah di beberapa daerah yang ada di Indonesia dalam tujuh kalipelayarannya dan kegiatan agama Islam tetap diselenggarakan. Di Semarangmisalnya, Cheng Ho melakukan pendekatan damai dengan menggunakanmedia wayang yang dianggap efektif untuk menyebarkan agama Islam yangdise-suaikan dengan karakteristik masyarakat di wilayah tersebut.Cheng Ho giat dan terlibat aktif dalam penyebaran agama Islam baik diChina maupun negara-negara lain yang dikunjungi. Kegiatan-kegiatan dalambidang agama Islam yang dilakukan Cheng Ho, antara lain, berziarah dipekuburan para pendahulu Islam dan sholat di masjid. Pengetahuannya tentang ajaran agama Islam sangatdalam karena dibesarkan dalam suasana keagamaan Islam serta Ayah danKakeknya adalah Muslim yang taat. Bahkan beberapa sarjana di Asia Tenggaramemberikan pernyataan bahwa Cheng Ho telah melaksanakan

\footnotetext{
${ }^{28}$ Mumuh Muhsin, "Islam di antara China dan Nusantara", Makalah dalam BedahBuku, oleh Selasar Pusat Kajian Lintas Budaya, Bandung: Universitas Padjajaran, 2007, h. 15
} 
rukun Islammenunaikan ibadah haji ke Mekkah. ${ }^{29}$

Dengan demikian, penjelasan di atas menunjukkan adanya bukti bahwaIslam juga hadir melalui China. Adapun Cheng Ho merupakan aktor utama yangberperan aktif dalam penyebaran Islam ke Indonesia. Meskipun kedatanganChina tidak bisa dikata-kan murni dakwah, namun dalam ekspedisinya Cheng $\mathrm{Ho}^{30}$ ikut berperan dalam dakwah meluaskan Islam. Dalam menjalankan misi dariDinasti Ming, perjalanan serta pelayaran yang dilakukannya mempunyai artiyang sangat penting bagi rakyat China. Selain itu pengaruh yang dihasilkandari hasil pelayarannya tidak hanya dirasakan bagi rakyat China saja, namun juga memberikan penga-ruh bagi umat Islam Nusantara.

\section{Kultur Cina-Javanese Muslim}

Menurut Sumanto al-Qurtubi, masuknya Islam ke Jawa abad ke 15 dan 16 ditandai dengan zaman SinoJavanese Muslim Culture dengan bukti dilapangan seperti konstruksi Mesjid Demak (terutama soko tatal penyanggamesjid), ukiran batu padas di Mesjid Mantingan, hiasan piring dan elementertentu pada mesjid Menara di Kudus, ukiran kayu di daerah Demak, Kudusdan Jepara, konstruksi pintu makam Sunan Giri di Gresik, elemenelemen yangterdapat di keraton Cirebon

\footnotetext{
${ }^{29}$ Kong Yuanzhi, Muslim Tionghoa Cheng Ho, h. $36-39$

30 Sebagaimana penelitian Fajar Affandi, ekspedisi pelayaran laksamanaCheng Ho membawa 63 kapal dengan awak berjumlah 27.000. salah satu rom-bongannya adalah Syekh Hasanuddin atau Syaikh Quro dari Campa. Tujuannya juga membawa misi dakwah. Keberadaan Syaikh Quro serta awak kapal yang notabenenya Muslim menunjukkan Cheng Ho memiliki misi dakwah Islam ke daerah yang dikunjunginya. Lihat, Fajar Apandi, "Islamisasi di Jawa Barat Abad XV", Skripsi Fakultas Adab dan Humaniora, UIN Syarif Hida-yatullah Jakarta, 2011, h. $5-6$
}

beserta taman Sunyaragi, dan sebagainya. $^{31}$

Kemudian teori lain tentang masuknya Muslim China melalui para tokoh yang menjadi aktor penyebaran Islam di tanah Jawa. Menurut Slamet Muljana, telah terjadi verbastering dari nama China ke nama Jawa. Nama Bong Ping Nang, misalnya, kemudian terkenal dengan nama Bonang.Raden Fatah yang punya julukan pangeran Jin Bun, dalam bahasa China berarti“"yang gagah". Raden Sahid (nama lain Sunan Kalijaga) berasal dari kata "Sait" $(\mathrm{sa}=3$, dan it $=1$; maksudnya 31 ) sebagai peringatan waktu kelahirannya dimasa ayahnya berusia 31 tahun. ${ }^{32}$

Slamet Muljana menguatkan pendapatnya bahwa Sultan Demak Panembahan Patah, dalam Kronik Sam Po Kong bernama Panembahan JinBun, nama bahasa China. Arya Damar sebagai pengasuh Panembahan Jin Bun padawaktu di Palembang bernama China, Swang Liong. Sultan Trenggonodisebutkan dengan nama China yaitu, Tung Ka Lo. Sedangkan Wali Sangaantara lain Sunan Ampel dengan nama China Bong Swee Hoo. Sunan GunungJati dengan nama China Toh A Bo. ${ }^{33}$

Sementara itu A.M. Suryanegara dalam penelitiannya tentang budaya China menyebutkan sejarah nama tempat yang bukan negeri China, dan nama orang yangbukan bangsa China, yang kemudian di-Chinakan penulisannya. Sebagai contoh putri rajaVikramawardana (Raja Kerajaan Majapahit terakhir) adalah Shita dan sebagaiRatu kerajaan Hindu Majapahit, dituliskan nama Chinanya yaitu Su King Ta.Kemudian nama kerajaan Budha Sriwijaya dituliskan dengan nama China, SanFo Tsi. Hanya saja kata

\footnotetext{
${ }^{31}$ Sumanto al-Qurtuby, Arus ChinaIslam-Jawa, Yogyakarta: Inspeal AhimsakaryaPress, 2003, h. 230

${ }^{32}$ Sumanto al-Qurtuby, Arus ChinaIslam-Jawa..., h. 225

${ }^{33}$ Slamet Muljana, Runtuhnya Kerajaan Hindu-Jawa..., h. 78
} 
Slamat Muljana, tidak disebutkan secara jelas bahwa RatuShita atau Su King Ta adalah orang peranakan China dan kerajaan BudhaSriwijaya atau San Fo Tsi adalah kerajaan China. ${ }^{34}$

Selain catatan sejarah, bukti peninggalan masa lalu juga menjadi symbolmasuknya Islam melalui China. Salah satu buktinya adalah Masjid di Surabayayang diberi nama masjid Muhammad Cheng Ho. Masjid tersebut mirip denganMasjid Nie Jie di Beijing. Bangunan didominasi cat warna merah, kuning, danhijau. Masjid tersebut dibangun sebagai bentuk penghormatan terhadapketeladanan Cheng Ho, seorang muslim yang cinta damai dan berwawasanluas. $^{35}$

Dari data di atas maka dapat dipahami bahwa secara keseja-rahan terdapat peran dan keterlibatan bangsa Tionghoa dalam penyebaran Islam ke Nusantara, setidaknya saat ekspedisi Cheng Ho dan peninggalan-peninggalan arsitektur khas China. Hanya saja beberapa asumsi tentang penelusuran nama-nama dan istilah China seperti disebut Muljana dipandang meragukan dan berada di luar konteks.

\section{Masyarakat Muslim Tionghoa di Sumatera Barat}

1. Kedatangan Masyarakat Muslim Tionghoa

$$
\text { Kehadiran orang-orang }
$$

Tionghoa di Indonesia, termasuk di Sumatera Barat dapat dikaitkan dengan beberapa peristiwa sejarah. Konon pada sekitar tahun 1930-an di negeri China terjadi pemin-dahan besar-besaran kaum pedagang dari bagian utara ke selatan oleh kaisar Tsi Huang Thi. Dalam buku Lord of The Rims (Taipan dari Pesisir) yang ditulis Sterling Seagrave, disebutkan empat alasan Kaisar dalam upaya menyatukan daratan Cina.

\footnotetext{
${ }^{34}$ Slamet Muljana, Runtuhnya Kerajaan Hindu-Jawa..., h. 96

${ }^{35}$ Fadil Satrio Wicaksono, "Peranan Cheng Ho"..., h. 2
}

Pertama, Tsi Huang Thi takut dengan ilmu suap bapak kandungnya, (Perdana Menteri Lu Pei Wei), ikut menyebar pada pedagang yang merupakan pendukung bapaknya. Seperti diketahui Tsi Huang Thi adalah anak hubungan gelap antara Perdana Menteri Lu Pei Wei dengan selir Kaisar. Lu Pei Wei menaruh gundik yang sudah hamil menjadi selir Kaisar.Ketika Tsi Huang Thai berumur 10 tahun ia diangkat jadi Kaisar dan Lu Pei Wei menjadi Perdana Menteri selama 10 tahun, yang merupakan satu-satunya perdana menteri dari gologan pedagang selama sejarah Cina.

Kedua, Cina Utara terkenal dengan pertanian. Di sini pemindahan besar-besaran kaum pedagang merupakan pembersihan terhadap kaum pedagang oleh para petani, sekaligus inisiatif Kaisar dalam menumbuhkembangkan populasi orang Cina wilayah di Selatan.

Ketiga, Adanya pandangan kaum orthodok Confucianisme yang ternyata memandang rendah kaum pedagang, menempatkan kaum pedagang dibawah petani. Dalam hal ini berlaku pandangan bahwa para petani sebagai masyarakat "penghasil" -- yang dapat menghasilkan sesuatu berupa padi, sedangkan kaum pedagang tidak menghasilkan apa-apa. Logika inilah yang mengantarkan superioritas kaum petani dari para pedagang, sehingga muncul inisiasi Kaisar untuk memerintahkan pemindahan kaum pedagang secara besar-besaran ke daerah selatan, yaitu (Fu Jian, KwangTong).

Kaum inilah yang kemudian menyebar ke seluruh dunia yang diperkirakan mencapai 55 juta orang. Empat persen dari jumlah total seluruh penduduk negeri yang juga dikenal dengan sebutan Tiongkok.Penyebaran itu merupakan invansi ketiga masyarakat Cina menuju dunia luar dimana gelombang pertamanya dilakukan olehLaksamana Cheng Ho sekitar enam ratustahun yang lalu. 
Laksamana yang diketahui belakangan beragama Islam, membawa pasukannya menelusuri daerah-daerah selatan. Dalam catatan sejarah disebutkan bahwa Cheng Ho sempat singgah di Jawa dan membuat perjanjian dengan raja dan penduduk setempat.

Sementara itu penyebaran kedua terjadi saat perang opium melanda Cina pada 1840 M. Dinasti Qing yang berkuasa mencoba menghentikan opium. Tetapi, karena Inggris melihat potensi besar pada perdagangan ini, mereka kemudian mengirimkan kapal perang sebagai jawaban. Cina kalah dan ditandanganilah perjanjian yang membolehkan Inggris berdagang candu dan menyerahkan Hong-kong dalam pangakuan Ratu Inggris.Kondisi dalam negeri yang sengkarut ini disinyalir memaksa masyarakat Cina melarikan diri ke negeri-negeri lain, termasuk ke wilayah Nusantara. Mereka menyebar ke daerah Asia bagian selatan dan Asia Tenggara, termasuk wilayah Nusantara. Inilah awal mula teori orang Cina memasuki kawasan Sumatera Barat. Salah seorang warga China di Padang, saat diwawancarai mengatakan:

"Saya memang lahir di Kota Padang dan sudah tinggal di sini lebih dari 50 tahun. Orang tua dan kakek nenek saya dulu sudah tinggal di sini. Sejak kecil kedua orang tua saya ikut ke Indonesia. Sebenarnya tujuannya bukan ke Indone-sia, tetapi Filipina. Tapi karena diserang badai di tengah lautan, lalu terdampar di Bagan Si Api Api. Nah seiring waktu berjalan akhirnya sampai di Padang, menetap di Padang". ${ }^{36}$

Pengakuan warga di atas mungkin merupakan bagian dari masyarakat China yang datang ke Sumatera Barat pada gelombang kedua. Kebenaran fakta itu bisa diperkuat dengan umur Klenteng See Hin Kiong yang terletak di Kampung Cina yang diperkirakan dibangun pada tahun 1860 .

36 Wawancara dengan SD, salah seorang warga Tionghoa di Padang, 31 Juli 2018
Ini seperti dikatakan oleh Ernawati, peneliti etnis China di ranah Minang yang menurutnya klentengSee Hin Kiong pernah terbakar pada 1861.

\section{Tragedi China di Padang Pariaman}

Teori lain tentang keberadaan China di Padang adalah berasal dari Pariaman. Menurut Ernawati, dalam buku Asap Hio di Ranah Minang, bahwa komunitas Tionghoa di Sumatera Barat sudah berada di Pariaman sejak abad XII Masehi. Saat Aceh masuk ke Pariaman, kawasan ini menjadi surga bagi kaum pedagang di zaman itu. Pariaman menjadi pusat dagang di pesisir. Tak heran, pada 1630, Christine Dobbin, penulis buku "Gejolak ekonomi dan Kebangkitan Islam dan Gerakan Paderi, Minangkabau 17841847", memperkirakan perkampungan Cina sudah ada di Pariaman sejak lama. Sayangnya, sebuah peristiwa mengenaskan menjadi pemicu hengkangnya orang Cina dari wilayah Pariaman. Disebutkan bahwa pada masa pendudukan Jepang, seorang Cina membawa dua anak gadisnya ke kantor Jepang. Keadaan itu ditanggapi lain oleh para pemuda yang kebetulan melihatnya. Muncul dugaan dari masyara-kat setempat yang menyebut pengkhianatan oleh warga China tersebut. Para pemuda yang tersulut emosi itu kemudian membawa dua anak gadis China itu langsung ke pantai dan "dibelek" dengan kangso (sejenis perkakas yang terbuat dari almunium). ${ }^{37}$ Kejadian ini praktis membuat warga etnis pendatang ini ketakutan. Mereka berangsur-angsur meninggalkan Pariaman me-nuju ke arah Timur, sekitar wilayah Kota Padang. Memasuki tahun 60-an, seiring dugaan terjadinya

${ }^{37}$ Menurut Erniwati, serangan itu dilakukan tanpa peren-canaan. Makanya, alat yang disiapkan bukan senjata tajam biasanya untuk membunuh. "Lagi pula, itu hukuman bagi pengkhianat. Tidak orang Cina saja yang merasakan hukuman itu, pemuka masyarakat yang juga ikut menjadi mata-mata Jepang, mendapat hukuman yang sama.Lihat, Erniwati, Asap Hio di Ranah Minang, tt.tp 
pengkhianatan oleh etnis China terkait G $30 \mathrm{~S}$ PKI, terutama setelah tahun 1965, praktissulit menemukan lagi warga China di Pariaman. Pasca kejadian G $30 \mathrm{~S}$ PKI atau PRRI, perlahan orang China berangsur pindah ke Padang, tepatnya di kawasan pondok saat ini.Selain alasan "ketakutan" juga terdapat alasan ekonomi bisa juga dijadikan dasar. Saat itu, memasuki abad XVII, Pariaman tidak lagi dianggap ladang yang subur bagi perdagangan,sehingga tidak saja pedagang Cina yang meninggalkan, tetapi juga pedagang-pedagang dari daerah lain.

Menurut Ernawati, diperkirakan ada 12 ribu masyarakat China yang tinggal di Padang. Beratus-ratus marga atau suku yang mendiami. Tetapi, hanya delapan suku yang punya rumah pertemuan. Kedelapannya adalah suku Gho, Lie-Kwee, Tan, Ong, Tjoa-Kwa, Lim Hwang dan Kho. Marga Kho merupakan marga terakhir yang membangun rumah pertemuan. Sesuai namanya, rumah pertemuan memang digunakan untuk mengadakan acaraacara yang melibatkan satu keluarga. Misalnya pada Imlek (tahun baru Cina), Cap Go Meh (hari ke 15 dari perayaan imlek), Kio, Sipasan atau Pek Chun (hari raya yang memperingati puncak musim panas). Bahkan, pada ulang tahun ke 140, keluarga Lie-Kwee berencana mengundang seluruh suku Lie-Kwee yang berada di Indonesia.

Bagi masyarakat China, kekerabatan menjadi perkara paling penting dari segala persoalan kehidupan. Dan seperti "adat" orang Asia Tengah (Jepang dan Korea), mereka sangat menjaga martabat keluarga. Demi martabat keluarga, maka apabila terjadi perkara memalukan, mereka tidak segan-segan untuk melakukan bunuh diri atau dibuang dari keluarga. Ini merupakan sikap dasar bagi orang China yang dipengaruhi oleh ajaran Confunsius dan Tao yang melekat pada setiap orang mereka.
Dari Mana Muslim Tionghoa di Sumatera Barat?

Belum diketahui secara pasti asal muasal warga Tionghoa Muslim di Sumatera Barat, kecuali beberapa teori seperti ekpedisi Laksamana Cheng Ho di Nusantara. Teori lain, adanya migrasi bangsa China dari kalangan pedagang yang menyebar ke wilayah Asia Selatan, termasuk ke wilayah Indonesia. Di negeri asalnya, memang terdapat beberapa suku China yang menjadi penganut agama Islam. Pada umumnya mereka dikenali sebagai komunitas "Hui", atau disebut Pinyin dalam bahasa Cina, atau Huizú, Xiaoerjing, atau dalam bahasa Arab ditulis "Huizu". Mereka merupakan satu kumpulan etnikorang Cina, yang biasanya dibedakan dengan perilku dan amalan keagamaan mereka, yaitu agama Islam. Mereka membentuk satu dari56 kumpulan minoritasyang secara sah diakui oleh pemerintah Republik Rakyat China. Mereka tinggal di barat laut China, yaitu wilayahNingxia, Gansu, Xinjiang. Kebanyakan budaya orang Hui menyamai orang Han, kecuali mereka adalah pengamal ajaran Islam, sehingga mereka mem-punyai beberapa ciri-ciri kebudayaan yang khas. Contohnya, sebagai orang Islam, mereka tidak memakan babi yang merupakan daging yang biasa dimakan dalam budaya China, dan mereka juga tidak memakan anjing, kuda, kebanyakan burung serta binatangbinatang yang dianggap istimewa dalam masakan China. Dalam hal pakaian, mereka juga memiliki perbedaan dimana laki-laki dewasa memakai kopiah putih dan wanita dewasa memakai tudung atau burdahsebagaimana yang biasa dalam budaya Islam. ${ }^{38}$

Dalam penggunaan modern, definisi Hui tidak memasukan kumpulan etnik seperti Uyghur, yang tinggal di China dan mengamalkan ajaran Islam, tetapi adalah orang

\footnotetext{
${ }^{38}$ Lihat,https://ms.wikipedia.org/wiki/O
} rang_Hui 
Turkik, sehingga berbeda budayanya dari pada orang Han. Contohnya, di Xinjiang-Kawasan Auto-nomi Ugyhur, yang didiami oleh $10 \%$ orang Hui, orang Hui mempunyai identitas etnik yang tersendiri berbanding Ugyhur, Kazakh, dan Kyrgyz yang merupakan orang-orang Turkik.

Termasuk di kalangan orang Hui menurut statistik China adalah orangorang Utsul di wilayah selatan Hainan, yang bertutur dalam sebuah bahasa Austonesia, bahasa Tsat yang berkaitan dengan bahasa minoritas Islam Champa Vietnam, dan yang dikatakan berketurunan orang Champa yang berhijrah ke Hainan. Kemudian istilah tradisional Cina bagi Islam adalah Pinyin: Huíjiào, yang secara harfiah berarti "agama orang Hui"), walaupun istilah yang paling tersebar luas merupakan transliterasi "Pinyin" dengan 'Yīsilán jiào, yang berarti "agama Islam". 39

\section{KESIMPULAN}

Data-data di atas menjelaskan bahwa selain ekspedisi kedatangan Cheng Ho ke Nusantara (termasuk Sumatera Barat) yang membawa orangorang beragama Islam yang kemudian sebagiannya menetap di wilayah ini, juga terdapat migrasi etnis Tionghoa dari komunitas "Hui" yang nota bene pemeluk agama Islam ke wilayah ini.

\section{DAFTAR KEPUASTAKAAN}

Azyumardi Azra, Jaringan Ulama Timur Tengah dan Kepulauan Nusantara Abad XVII \& XVII: Akar Pembaharuan Islam Indonesia, Jakarta: kencana Prenada MediaGroup, 2004.

Abd. Ghofur, "Tela'ah Kritis Masuk dan Berkembangnya Islam di Nusantara" dalam Jurnal Ushuluddin, Vol. XVII No. 2, Juli 2011.

Ahmad Mansur Surya Negara, Menemukan Sejarah, Wacana Pergerakan Islam diIndonesia, Bandung: Mizan 2002.

Fajar Apandi, "Islamisasi di Jawa Barat Abad $X V$ ”, Skripsi Fakultas Adab danHumaniora, UIN Syarif Hidayatullah Jakarta, 2011.

Fadil Wicaksono, "Peranan Cheng Ho dalam Perkem-bangan Agama Islam diIndonesia Tahun 14051433" dalam Skripsi Universitas Pendidikan Indonesia, Bandung, 2014.

Kong Yuanzhi, Muslim Tionghoa Cheng Ho: Misteri Perjalanan Muhibbah diNusantara, Jakarta: Yayasan Pustaka Obor, 2000

Ricklefs, Sejarah Indonesia Modern 1200-2008, Jakarta: PT. Serambi Ilmu Sejahtera, 2010.

M. Abdul Karim. "Teori Jalur India Tentang Masuknya Islam di Indonesia (Studi Teori Bangla dan Gujarat)", Makalah tanpa tahun terbit, h. 15

M. Naquib al-Attas, Islam and Secularisme, Kuala Lumpur: ISTAC, 1993. 
Mumuh Muhsin, "Islam di antara China dan Nusantara", Makalah dalam BedahBuku, oleh Selasar Pusat Kajian Lintas Budaya, Bandung: Universitas Padjajaran, 2007.

Naquib al-Attas, Islam dalam Sejarah Melayu, Bandung: Mizan, 1997

Rosita Baiti, "Teori Dan Proses Islamisasi Di Indonesia" dalam Jurnal Wardah, no.XXVIII/ th. XV/Desember 2014.

Rizal Sukma dan Clara Joewono, Gerakan Pemikiran Islam Indonesia Kontemporer, Yogyakarta: Kanisius, 2007.

Ira Lapidus. M, Sejarah Sosial Umat Islam, Jakarta: PT Raja grafindo, 1999.

Slamet Muljana, Runtuhnya Kerajaan Hindu-Jawa dan Timbulnya Kerajaan Islamdi Nusantara, Yogyakarta: LKiS, 2007.

Sumanto al-Qurtuby, Arus China-Islam Jawa; Bongkar Sejarah Atas Peranan Tionghoa Dalam PenyebaranAgama Islam di Nusantara Abad XV-XVI.

Sumanto al-Qurtuby, Arus China-IslamJawa, Yogyakarta: Inspeal AhimsakaryaPress, 2003.

Tan Ta Sen, Cheng Ho: Penyebar Islam Dari China ke Nusantara, Jakarta:Kompas, 2010. 